\title{
Remote Sensing at the Horace Cabe Site (41BW14)
}

Chester P. Walker

Archaeo-Geophysical Associates, LLC

Timothy K. Perttula

Heritage Research Center, Stephen F. Austin State University

Follow this and additional works at: https://scholarworks.sfasu.edu/ita

Part of the American Material Culture Commons, Archaeological Anthropology Commons, Environmental Studies Commons, Other American Studies Commons, Other Arts and Humanities Commons, Other History of Art, Architecture, and Archaeology Commons, and the United States History Commons

Tell us how this article helped you.

This Article is brought to you for free and open access by the Center for Regional Heritage Research at SFA ScholarWorks. It has been accepted for inclusion in Index of Texas Archaeology: Open Access Gray Literature from the Lone Star State by an authorized editor of SFA ScholarWorks. For more information, please contact cdsscholarworks@sfasu.edu. 


\section{Remote Sensing at the Horace Cabe Site (41BW14)}

Creative Commons License

(c) (i) (8)

This work is licensed under a Creative Commons Attribution-NonCommercial 4.0 International License 


\title{
Remote Sensing at the Horace Cabe Site (41BW14)
}

\author{
Chester P. Walker \\ Archaeo-Geophysical Associates, LLC \\ and \\ Timothy K. Perttula \\ Archeological \& Environmental Consultants, LLC
}

\section{INTRODUCTION}

A magnetometer survey was conducted at the Horace Cabe Mound site (41BW14) in 2005 by Walker and Schultz (2006) as part of the Bowie County Levee Realignment project in Bowie County, Texas (Sundermeyer et al. 2006). The purpose of the survey was to attempt to locate anomalies that may represent potential archaeological features at this important Late Caddo mound center near the Red River. The area was surveyed using a Geometrics portable G858 cesium sensor magnetometer and a G-856 proton magnetometer base station. This article puts on record another substantive example of Caddo archaeology as seen through the use of remote sensing technology.

The original processing and interpretation of this data presented in Sundermeyer et al. (2006) are not simply re-hashed here. Further data processing has revealed several possible Caddo structures on and in the immediate vicinity of Mounds $\mathrm{B}$ and $\mathrm{C}$ at the Cabe site.

\section{THE KNOWN ARCHAEOLOGY OF THE HORACE CABE SITE}

The Horace Cabe site is a Haley (ca. A.D. 1200-1400) and Texarkana (ca. A.D. 1400-1700) phase Caddo mound center on natural levee alluvial deposits along Summerhill Lake, a channel lake in the meander belt of the Red River (Perttula et al. 1995; Guccione and Hays 2006; Sundermeyer et al. 2006). The current channel of the river is $2.5 \mathrm{~km}$ to the north of the site.

There are eight constructed mounds at the Cabe site (Perttula et al. 1995: Figure 4), seven of which (Mounds A-G) are part of a cluster of mounds in a single group. The mounds and associated known habitation areas cover approximately 55 acres. The recovery by collectors of shell-tempered McKinney Plain, Simms Engraved, Barkman Engraved, Belcher Ridged, Taylor Engraved, Avery Engraved, Nash Neck Banded, Emory PunctatedIncised, and Bailey Engraved vessels indicate that the main Caddo use of the mounds and much of the habitation areas was during the latter part of the Texarkana phase. Glass beads have been recovered by collectors from Cabe, further suggesting some use of the site in the latter part of the 17th century and early part of the 18th century A.D.

Five of the mounds (Mounds A-E) are arranged in a semi-circular or U-shaped pattern with an open area to the south (Figure 1). Mounds F and G lie some distance to the west of Mound D, which is ca. $10 \mathrm{~m}$ west of 
Mound C. There is a slightly raised $(\mathrm{ca} .40 \mathrm{~cm}$ ) or higher platform area between Mounds A and E. This platform is apparently composed of midden deposits and possible fill from mound erosion (Perttula et al. 1995). The platform probably functioned as a deliberately constructed plaza.

Mounds A-C are between 0.85 and $2 \mathrm{~m}$ in height, and Mound A is the largest at Cabe, measuring $25 \mathrm{~m}$ in diameter (see Figure 1). Mounds B and C are between 18 and $21 \mathrm{~m}$ in diameter. These three mounds appear to be part of a single conjoined mound, probably covering a series of Caddo temple structures (cf. Webb 1959).

Available archaeological evidence (mainly profiles of potholes and noted artifacts) indicates that Mound A was built in two stages, with Caddo structures at the base of the mound and atop the final mound stage. These structures were burned and then capped with earthen mound fill. Both Mounds B and C were likely built to cover special purpose structures on the crest of the mounds that were used by the Caddo political elite. Large amounts of daub in a pothole between Mounds B and C suggest that a structure may have also stood in this area, as well as on or near the crest of each mound. A pothole on the platform area showed a dark midden zone almost $1 \mathrm{~m}$ in thickness, but no evidence of structures. Mound D also contained evidence of burned structures as well as human skeletal remains, apparently from disturbed Caddo burials placed in the mound. Little is currently known about Mounds E-G.

The Texarkana phase mounds at the Horace Cabe site contain archaeological evidence for the construction, burning, and deliberate burial of daub-covered Caddo structures. We can expect burned Caddo structures on the crest and base of the mounds, as well as in areas between the conjoined mounds (Mounds A-C), and on flatter and lower mound areas overlooking the platform or plaza. Only thick midden deposits have been reported from the platform area.

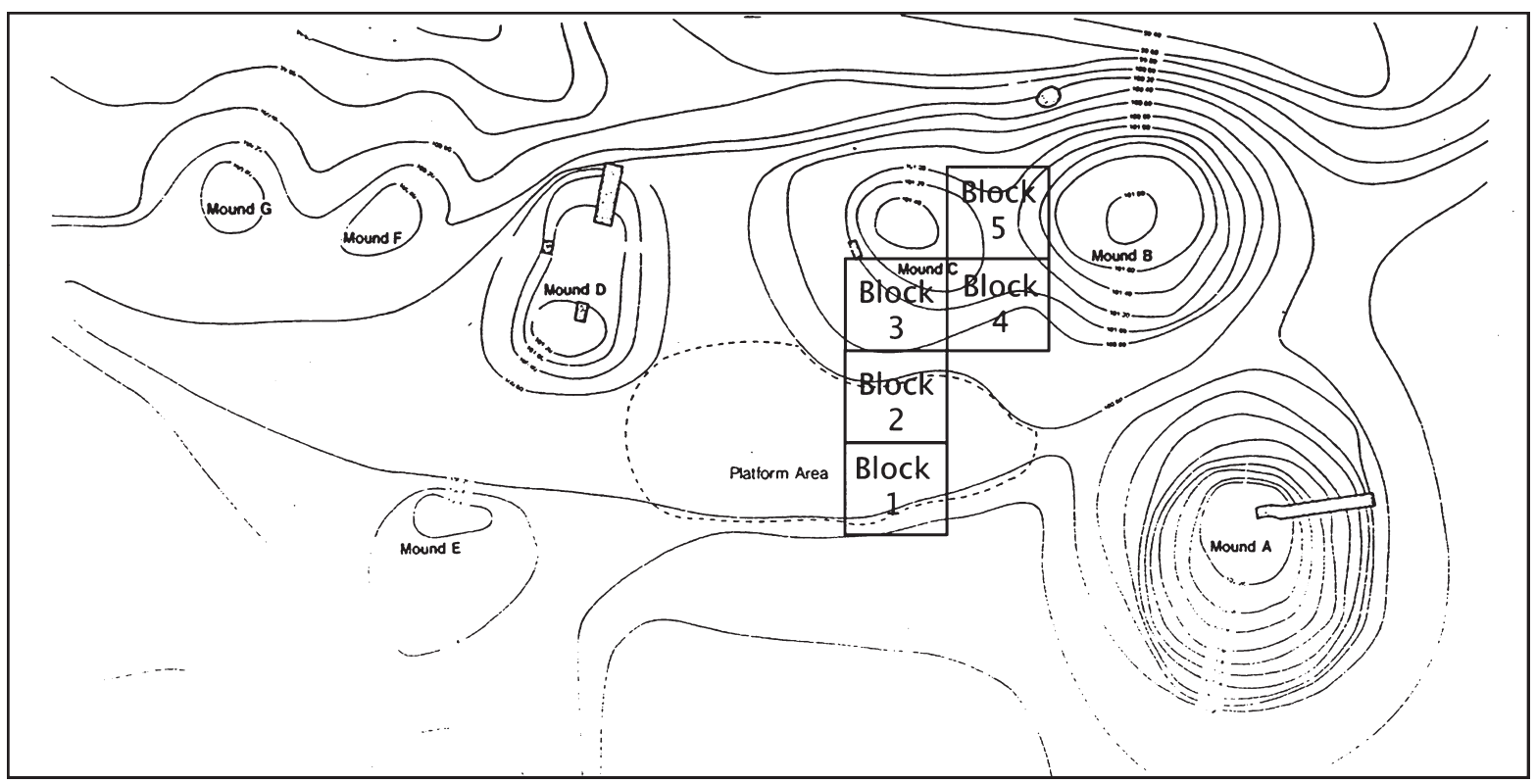

Figure 1. Map of the Cabe site (41BW14) with grid locations. 


\section{REMOTE SENSING METHODS}

A total of $720 \times 20 \mathrm{~m}$ grids were placed at and around the Cabe site as part of the Bowie County Levee Realignment project. Five grids were collected on the main part of the Cabe site (see Figure 1) and two more grids were collected to the south across Langdon Road (CR 2342) in hopes of detecting possible prehistoric Caddo habitation areas.

Magnetometer data in both areas were collected in adjacent $20 \times 20 \mathrm{~m}$ blocks that were oriented north-south. The hand-held counterbalanced staff was used with two sensors spaced $50 \mathrm{~cm}$ apart. The center of the handheld staff was carried along the survey line, allowing for each sensor to extend $25 \mathrm{~cm}$ on either side. Survey lines were spaced at $1 \mathrm{~m}$ intervals with data collected on a 0.1 second interval, thus collecting approximately 10 readings per $\mathrm{m}$. A G- 856 proton magnetometer base station was used to collect data at 10 second intervals in order to record the ambient magnetic presence or observed diurnal variation.

Collected remote sensing data were downloaded using MagMap 2000. Employing MagMap 2000, the base station diurnal correction was applied to the files, and grid coordinates were assigned to each collection block. Magnetometer data were imported into ArchaeoSurveyor 2.0 and a composite was created, combining the individual grids into a master grid. Metal debris and possible buried pipelines or cables did obscure to some extent the remote sensing data for these Cabe site areas. Because of this, data processing was a bit complex and differed from block to block; detailed descriptions of data processing accompany the discussion of the remote sensing findings for each area.

\section{REMOTE SENSING FINDINGS AT THE HORACE CABE SITE}

\section{South of Langdon Road}

Magnetometer data from south of the Langdon Road (CR 2342) were collected in two 20 x 20 m blocks. Unfortunately, the remote sensing data in both of these blocks was severely obscured by magnetic debris, and no useful archaeological information was observable in this area (Figure 2).

\section{North of Langdon Road}

The five 20 x 20 m blocks north of Langdon Road were located in the platform area south of Mound C, along the southern flanks of Mound C, and along the western side of Mound B (see Figure 1). While the magnetometer data in these five blocks was also severely obscured by metallic debris, in this case it was possible to obtain some useful geophysical and archaeological information. Originally, Walker and Schultz (2006) identified one possible archaeological anomaly or feature (Feature 1 ) in the center of Block 1 (Figure 3).

\section{Feature 1}

Feature 1 is a horseshoe-shaped high return approximately $2.5 \mathrm{~m}$ in diameter. Due to the poor quality of the remote sensing data, despite the re-processing, it is not possible to determine if this is the geophysical signature of an archaeological feature. To the west of Feature 1 is a shallow northwest-running drainage ditch. Further north is an area of enhanced magnetic returns that corresponds with the area between Mounds B and C (See Figure 3). There are several other simple dipole returns spread across the blocks that are interpreted as metal debris. 


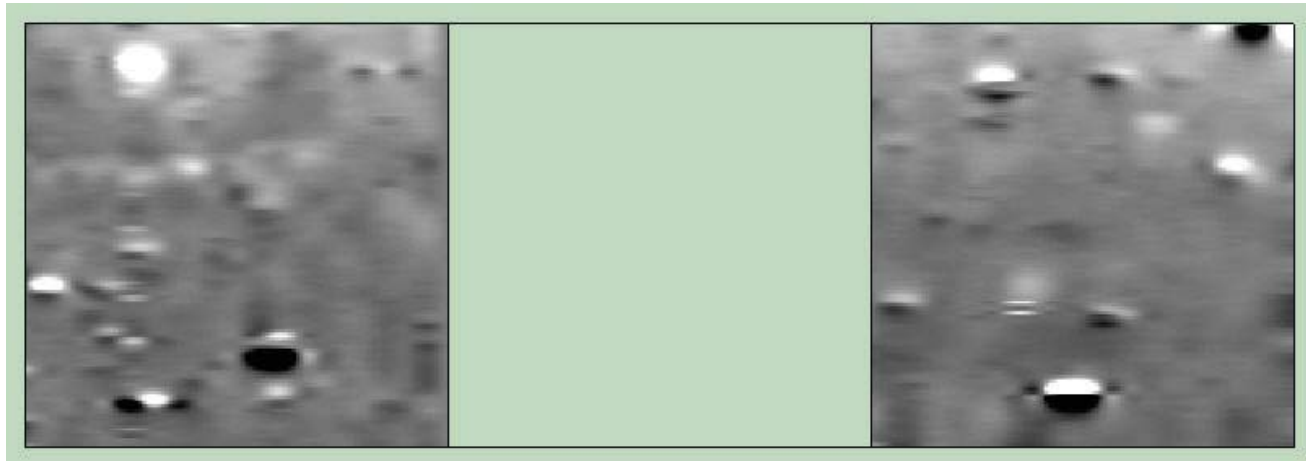

Figure 2. Plots of magnetometer grids south of Langdon Road (CR 2342).

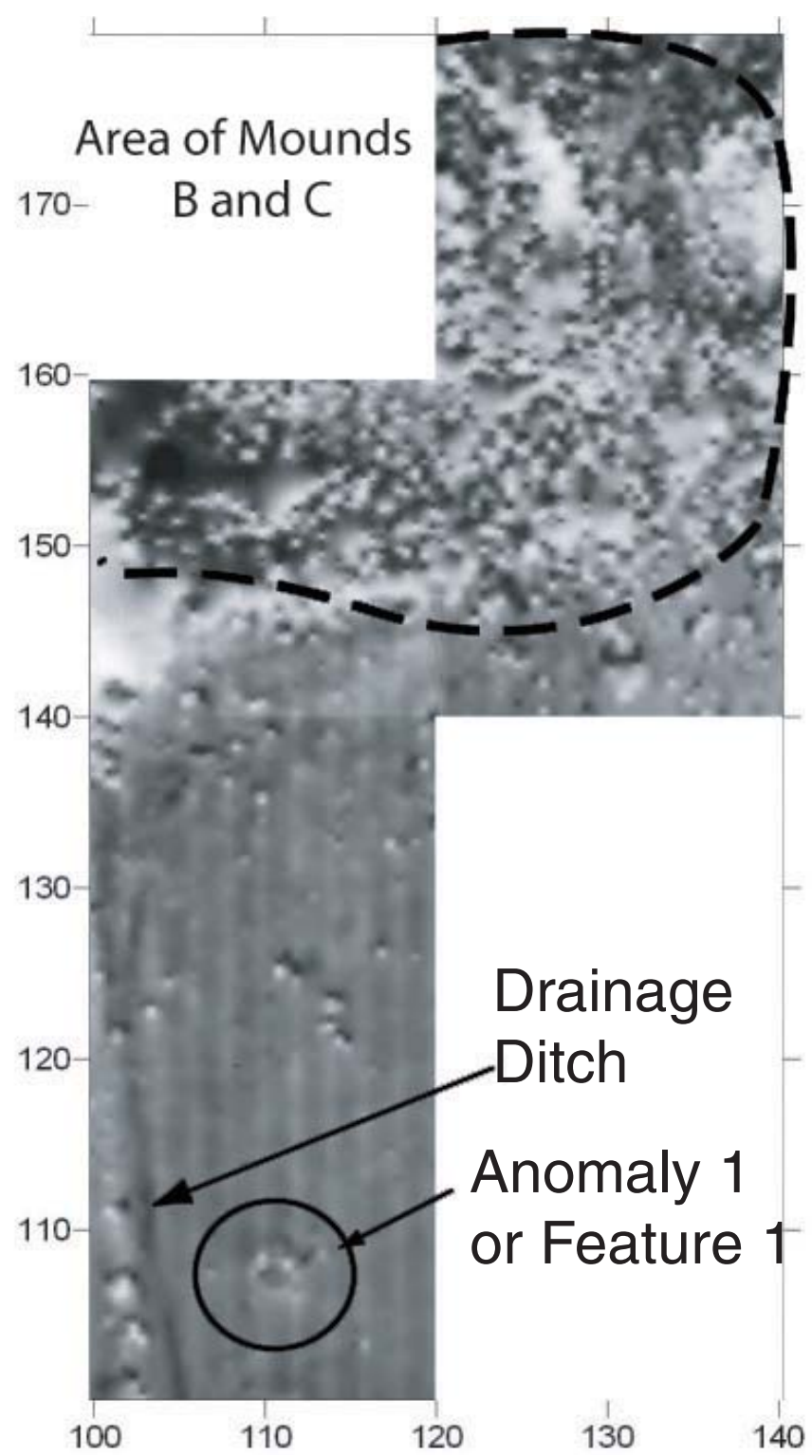

Figure 3. Original plots of magnetometer grids at the Cabe Site (41BW14). 
The main issue with the geophysical data at Cabe is the disturbance caused by metal debris at the site. The amount of metallic noise can be easily seen in a 3D view of the survey blocks (Figure 4). With the use of ArchaeoSurveyor 2.0, the remote sensing data from Cabe was re-processed and several additional archaeological features have been identified. The re-processing of the magnetometer data began with a de-spiking filter to remove spikes and dropouts. Due to the excessive amount of metal debris, this filter was passed through the data three different times: first with a mean threshold of 1.5 standard deviations (SD) with a $10 \times 10$ cell window; secondly with a 3 SD threshold and a $5 \times 5$ cell window; and finally with a 2.5 SD threshold and a $3 \times 3$ cell window. Next the data was clipped to 4 SD twice and at 3 SD for three iterations. A low pass Gaussian filter with a $3 \times 3$ cell window was also used, and the filtered data was interpolated so the $\mathrm{X}$ and $\mathrm{Y}$ axis matched. With this rather robust processing workflow, three new anomalies (Features 2, 3 and 4) became visible (Figure 5).

As can be seen in Figure 4, the majority of metallic noise is present in Block 4 in the southern part of Mounds B and C. This grid was simply removed from the composite created in ArchaeoSurveyor and the remaining magnetometer data then re-processed. Data was again de-spiked for three iterations, beginning with a threshold of 3 SD with a $10 \times 10$ cell window, next with a 2 SD threshold and a $7 \times 7$ cell window, and finally with a 1 SD threshold and a $3 \times 3$ cell window. These data were clipped to $3 \mathrm{SD}$, and a de-striping median traverse filter was passed through the data. Finally the data were interpolated so that the $\mathrm{X}$ and $\mathrm{Y}$ axis match. The result of this round of data processing (Figure 6) brought out much more spatial detail on all three of the new features, especially Feature 2 and 4 (Figure 7).

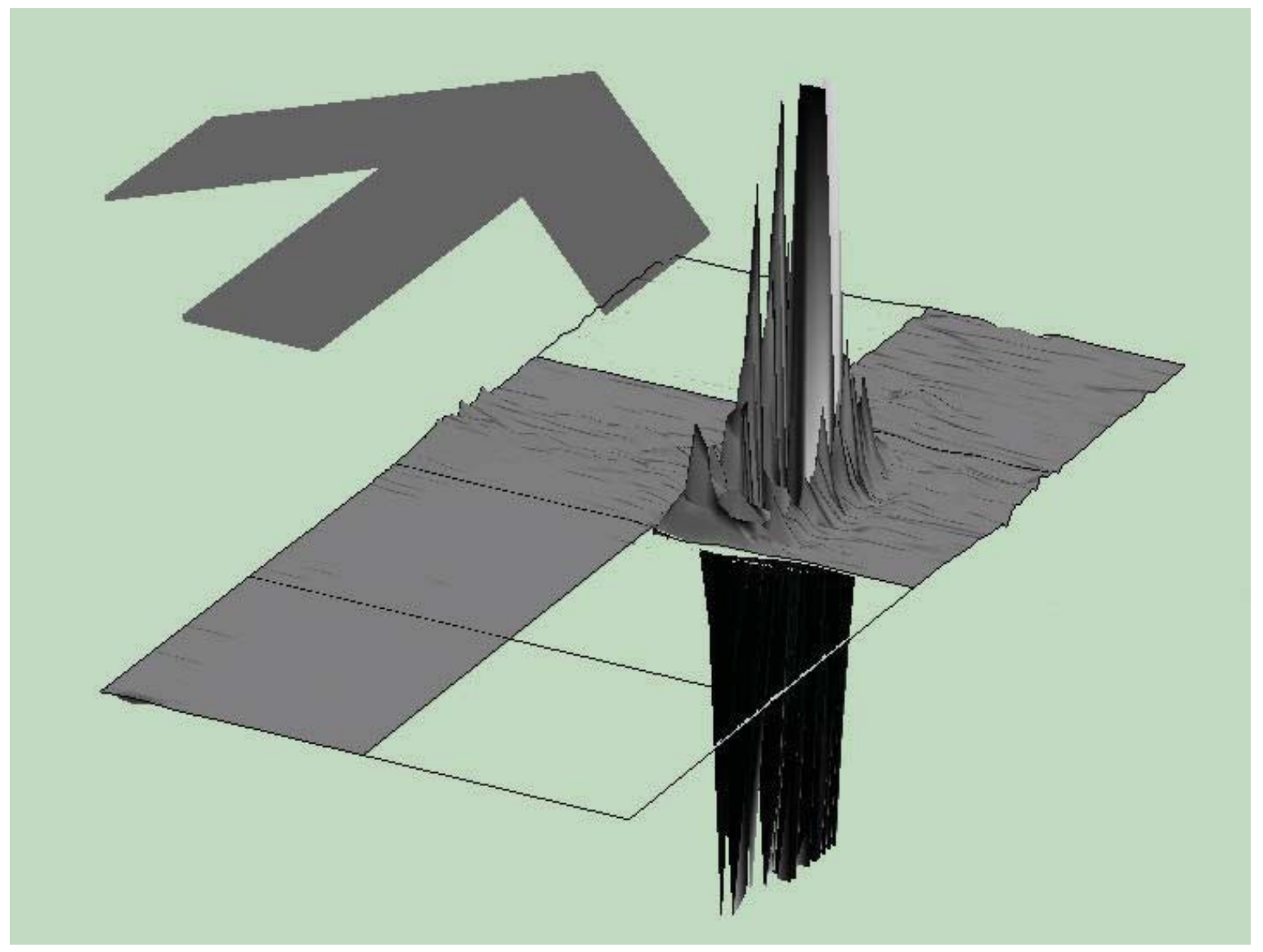

Figure 4. 3D Plot of magnetometer grids at the Cabe Site (41BW14). 


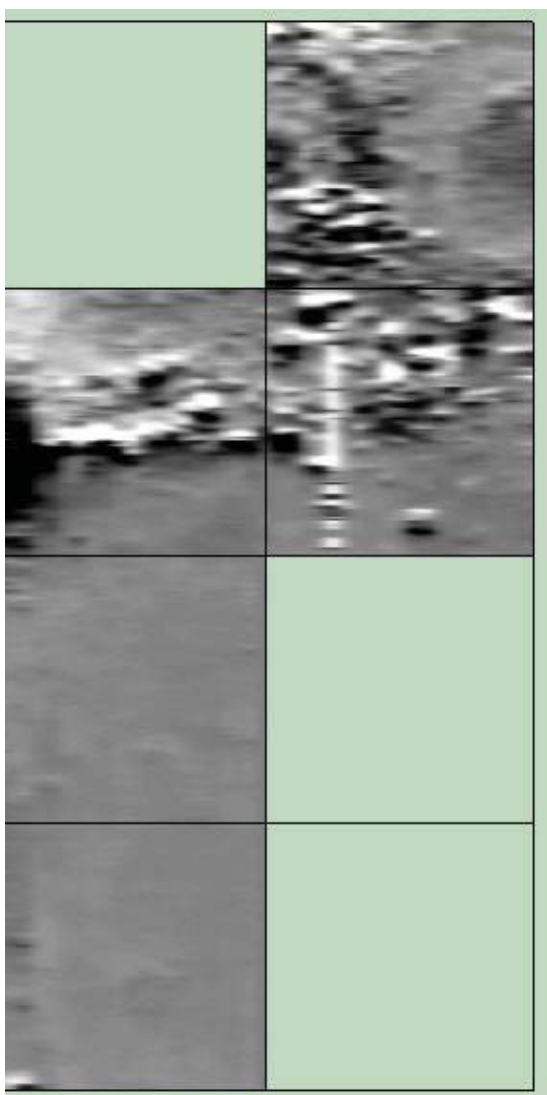

Figure 5. Plots of magnetometer grids from the Cabe Site (41BW14).

\section{Feature 2}

Feature 2 consists of a faint circular outline approximately $15 \mathrm{~m}$ north/south and $17 \mathrm{~m}$ east/west, positioned directly in front of Mound C. A strong return in the approximate center of the outline probably represents a central fire hearth within the outlines of a large prehistoric Caddo structure. Across the center of the feature is a series of complex dipole returns. These are more than likely noise resulting from some sort of buried pipe or pipeline.

\section{Feature 3}

Feature 3 is the most legible of the four geophysical features present in our remote sensing data from the Cabe site. The feature is approximately $16 \mathrm{~m}$ in diameter with a central hearth measuring approximately $2 \mathrm{~m}$ in diameter. This feature is located on the northwestern side of Mound C.

\section{Feature 4}

Feature 4 is the most ephemeral of the four features we have been able to define in the remote sensing work at Cabe. It was not clearly defined until the data was re-processed after the removal of Block 4 because of metallic noise. This feature is approximately $12 \mathrm{~m}$ in diameter and has a possible central hearth. Feature 4 is located on the northwestern corner of Mound B.

\section{DISCUSSION}

It is important to note that the geophysical features presented here from the Cabe Mound site are not nearly as obvious and easily definable as other geophysical features recently discovered at other East Texas Caddo sites such as the George C. Davis site and the Hill Farm site (Creel et al. 2004, Walker and Schultz 2006, Perttula et al. n.d.). It took a robust series of data processing before the geophysical features at Cabe were apparent.

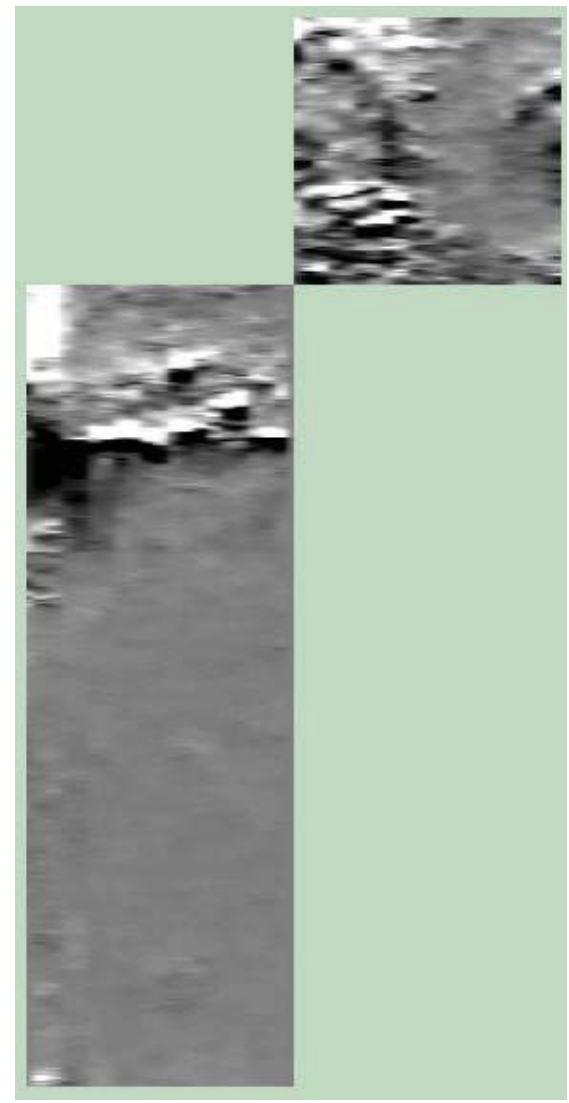

Figure 6. Plots of magnetometer grids with Block 4 removed. 
Nevertheless, it is our opinion that the geophysical features detected in the processing of the magnetometer data presented here represent prehistoric and/or early historic Caddo structures that were likely daub-covered. The structures were probably burned and then covered with earth during the construction and reshaping of the mounds at the Horace Cabe site. Large mound top structures are well known at other Caddo mound sites in East Texas and along the Red River (including such sites as George C. Davis, Belcher, and Hatchel, to name but a few), and it appears from the geophysical data that there were structures on at least two of the mounds at Cabe; the limited archaeological data suggest that Mounds A-D had structures on them.

It is exciting that even with the amount of noise caused by metal debris in the remote sensing blocks that geophysical returns as subtle as these created by archaeological features at the Cabe site can still be identified and are interpretable. We look forward to the opportunity to conduct more extensive remote sensing surveys on the other mounds at Cabe, as well as in the known habitation areas.

\section{ACKNOWLEDGMENTS}

We are grateful to John T. Penman, Scott Sundermeyer, and Ken Shingleton for permission to use the archaeological and remote sensing data from the Bowie County Levee project for this article. We also thank David Wilbourn of DW Consulting for developing an import routine for GeoMetrics Data into ArchaeoSurveyor 2.0.

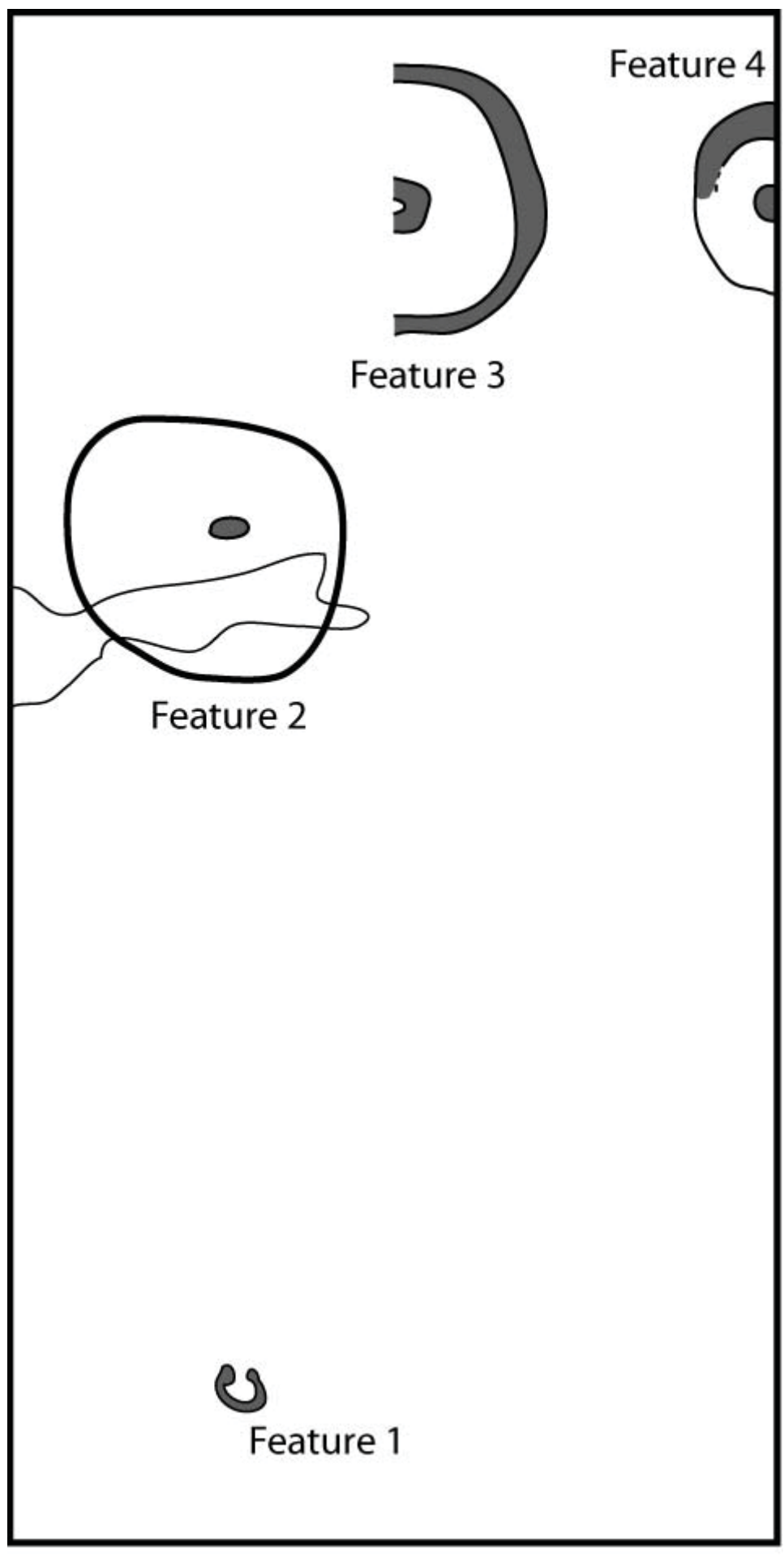

Figure 7. Interpretations of magnetometer data from the Cabe Site (41BW14). 


\section{REFERENCES CITED}

Creel, Darrell G., Dale Hudler, Samuel M. Wilson, T. Clay Schultz, and Chester P. Walker

2004 A Magnetometer Survey of Caddoan Mounds State Historic Site. Technical Report 51. Texas Archeological Research Laboratory, The University of Texas at Austin.

Guccione, Margaret J. and Phillip Hays

2006 Geomorphology, Sedimentology, and Vegetation History along the Red River Floodplain, Bowie County, Texas. In An Intensive Cultural Resources Survey and Remote Sensing and Geomorphological Investigations for the Bowie County Levee Realignment Project, Bowie County, Texas and Little River County, Arkansas, by Scott A. Sundermeyer, John T. Penman, and Timothy K. Perttula, with contributions by Timothy G. Baugh, Margaret J. Guccione, Michael Grealy, Lawrence B. Conyers, Dayna B. Lee, Robert Cast, Sherry N. DeFreece Emery, Phillip Hays, Charles A. Steger, Charles D. Neel, Chester P. Walker, T. Clay Schultz, and Myra L. McMinn, pp. $104-157$. Miscellaneous Reports, Report of Investigations No. 29. LopezGarcia Group, Dallas, Texas.

Perttula, Timothy K., Chester P. Walker, and T. Clay Schultz

n.d. A Revolution in Caddo Archaeology: The Remote Sensing and Archaeological View from the Hill Farm Site (41BW169) in Bowie County, Texas. MS in preparation.

Perttula, Timothy K., James E. Bruseth, Nancy A. Kenmotsu, and William A. Martin

1995 Archeological Testing at the Cabe Mounds (41BW14), Bowie County, Texas. Cultural Resource Management Report 8. Department of Antiquities Protection, Texas Historical Commission, Austin.

Sundermeyer, Scott A., John T. Penman, and Timothy K. Perttula, with contributions by Timothy G. Baugh, Margaret J. Guccione, Michael Grealy, Lawrence B. Conyers, Dayna B. Lee, Robert Cast, Sherry N. DeFreece Emery, Phillip Hays, Charles A. Steger, Charles D. Neel, Chester P. Walker, T. Clay Schultz, and Myra L. McMinn

2006 An Intensive Cultural Resources Survey and Remote Sensing and Geomorphological Investigations for the Bowie County Levee Realignment Project, Bowie County, Texas and Little River County, Arkansas. Miscellaneous Reports, Report of Investigations No. 29. LopezGarcia Group, Dallas, Texas.

Walker, Chester P. and T. Clay Schultz

2006 Magnetometer Survey and Results. In An Intensive Cultural Resources Survey and Remote Sensing and Geomorphological Investigations for the Bowie County Levee Realignment Project, Bowie County, Texas and Little River County, Arkansas, by Scott A. Sundermeyer, John T. Penman, and Timothy K. Perttula, with contributions by Timothy G. Baugh, Margaret J. Guccione, Michael Grealy, Lawrence B. Conyers, Dayna B. Lee, Robert Cast, Sherry N. DeFreece Emery, Phillip Hays, Charles A. Steger, Charles D. Neel, Chester P. Walker, T. Clay Schultz, and Myra L. McMinn, pp. 158-168. Miscellaneous Reports, Report of Investigations No. 29. LopezGarcia Group, Dallas, Texas.

Webb, Clarence B.

1959 The Belcher Mound: A Stratified Caddoan Site in Caddo Parish, Louisiana. Memoirs No. 16. Society for American Archaeology, Salt Lake City. 